\title{
Beef Quality Assurance Injection Sites and Techniques
}

\author{
Wei Li \\ Husbandry Research Institute of Heilongjiang Province \\ 2 He Yi Street, Qiqihar 161005, China \\ Tel: 86-452-611-6722Ｅ-mail: lottost@sohu.com \\ Yuanhu Yin (Corresponding author) \\ Husbandry Research Institute of Heilongjiang Province \\ 2 He Yi Street, Qiqihar 161005, China \\ Tel: 86-452-611-6751Ｅ-mail: Yinyuanhu@gmail.com
}

Fang Wang

Heilongjiang Academy of Agricultural Sciences, Qiqihar Branch Academy

53 Xin Ming Street, Qiqihar 161006, China

Tel: 86-452-272-2203 E-mail: wangfangnd@hotmail.com

\begin{abstract}
Shujun Miao
Animal Science and Technology, Heilongjiang August First Land Reclamation University College

Daqing 163319, China
\end{abstract}

Tel: 86-459-698-1507Ｅ-mail: shujun_m@126.com

Received: April 6, $2011 \quad$ Accepted: April 30, $2011 \quad$ Online Published: December 1, 2011

doi:10.5539/jas.v4n1p91

URL: http://dx.doi.org/10.5539/jas.v4n1p91

This Article is financed by project MATS-Beef Cattle system NO.NYCYTX-38

\begin{abstract}
Food safety has become a very important issue in our society. Modern livestock management practices rely upon the prudent use of injectable antibiotics and vaccines for the purpose of maintain herd health and productivity. Rasmussen (1980) concluded that both the active pharmaceutical and the carrier-vehicle administered are responsible for tissue injury. Now we need to put great emphasis on improper injections which can lead to trimming and discarding of expensive cuts, and learn to use a proper injection method to cause less injection site blemishes as a costly problem for the beef industry. This paper examines the effect of needle based injections and makes a case for using needle-free injections for all but intravenous targets. Results from research on estimating the value of carcass information and potential improvement in pricing accuracy with injections are reviewed. Lastly, management implications are discussed for producers choosing proper injection systems to fed cattle.
\end{abstract}

Keywords: Injection site lesions, Beef

\section{Introduction}

The purpose of the use of veterinary drugs is to achieve greater economic efficiency of cattle healing. Veterinary drugs are critical components of food-animal production which provide many benefits related to animal health, animal welfare, epidemic prevention. Drugs could be taken through oral administration, intramuscular injections, subcutaneous injections or intravenous injection to achieve the systemic absorption. The advantages of oral administration are safe and convenient for manipulation. However, injection is with more results in a higher 
absorption rate than oral administration, and the components of drugs cannot be damaged by digestive tract and feed nutrients. So injection plays a more significant role in the livestock industry. But people often overlook that lesion severity varies according to products injected intra-muscularly. Injections may result in animal stress, vaccine residues, injection site lesions, abscess, cross infection, and broken needles (McDowell et al., 2010). The first beef quality assurance program in the U. S. began in 1986. The National Cattlemen's Beef Association- Beef Quality Task Force in 1990 began to address concerns raised about lesions resulting from injections of animal health products (Dexter et al., 1994). One objective of the National Beef Quality Audit was to increase the percentage of cattle making it into the USDA Prime (Busby et al., 2001). In 1991 NBQA concluded that the industry lost an average of nearly $\$ 280$ in quality defects on every fed animal marketed and injection site blemishes as the second greatest concern to those who sell beef. Injection-site lesions still occur at an unacceptable frequency in the top sirloin butt and those lesions, if not removed entirely, can dramatically reduce the desirability of top sirloin steaks (George et al.,1996). The techniques, such as a needle-free injection system, injection guns and injections in neck, have been applied mostly in developed countries.

In the U.S., the incidence of injection-site lesions decreased from $21.3 \%$ in July of 1991 to $2.06 \%$ in July of 2000 (Dexter et al.1994, Roeber et al.2001), but the application in developing countries are minimal due to reasons related to economic growth, public concerns on food safety, environment and proper injections that cannot be ignored (Green et al., 1999).

\section{Injections effects on the Cattle Industry}

There are three common types of lesions that result from injections: active fluid-filled, "woody callous", and discoloration. In addition lateral transmission of blood-borne diseases can occur when a single needle is used repeatedly to vaccinate livestock. ( Beef Quality Assurance,2011).

Scientific studies show that injections that are given to beef can affect the beef quality - and, therefore, the value of beef harvested from those animals. In 1993 the incidence of injection-site blemishes in top sirloin butts was determined to be 10.87-2.99\%, with an average weight per blemish of $123.39 \pm 5.48 \mathrm{~g}$ (Dexter 1997). Injection-site lesion incidence in beef round cuts audited at retail and in steak-cutting facilities was 8.45 and $10.04 \%$ respectively, with an average lesion-trim of 314.7 and $191.59 \mathrm{~g}$ respectively and (George et al., 1995), and Svendsen et al. (1979) reported that muscle sections taken after injection with glycerol formol contained small amounts of normal fibers localized among necrotic muscle fibers.

Black leg bacterin/toxins and related clostridial products have long been known to cause visible injection site reactions if given under the skin. Colorado State University found that at slaughter (125days after injection), injection sites could be identified in 90 percent of the top butts, 85 percent of the rounds, and only 35 percent of the necks. The neck is a less expensive cut than the top butt or round, and it heals better than other sites. It is thus best to give it in the neck.

Moving all intramuscular injections to the neck area is the first step toward increasing beef's market efficiency. Injected in the neck could reduce the beef's incidence of injection site lesions.

Morgan et al.(2004) documented that visible tissue damage was limited in cattle that were treated with Biobullets 21,28 , and $35 \mathrm{~d}$ before slaughter. While the research indicates that the Biobullet administration method of ceftiofur sodium, when used at least 30 days prior to harvest, led to no detectable increase in tissue damage or tenderness. In the US, the incidence of injection-site lesions in top sirloin butts has not changed between July 1993 (10.91\%) and July 1995 (10.19\%). However, during this same period, the mean weight of injection-site lesion trim increased $(\mathrm{P}<0.05)$ from $102.63 \pm 12.56 \mathrm{~g}$ to $152.81 \pm 13.24 \mathrm{~g}$. Eighty percent of lesions examined during this period were classified as chronologically "older"(George et al. ,1996). The frequency of lesions in beef rounds significantly declined 5 percentage points between 1998 and 1999 and 6 percentage points between 1999 and 2000 in the US (Roeber, 2002).

All result in decreased meat tenderness and muscle tissue damage, and severe tissue changes accompany these lesions that can dramatically affect cut tenderness. Furthermore, deep muscle lesions are a big concern as they often reach the consumer undetected. Broken needles pose a food safety hazard in beef (Stier, 2003). Although it is of very low incidence, broken needles are not found until they reach the consumer's plate causing the consumer to lose confidence in beef (Dubeski 2001). In 2007 a National Market Cow and Bull Beef Quality audit revealed that cattle producers improved herd management techniques, animal welfare and handling, hide damage, injection-site location, and bruises in market cows and bulls from 1999 to 2007.

\section{Source of the lesions}

Initially, it was thought that feedlots were the primary source of the lesions that the lesions resulted from 
injections given when the cattle were processed at time of entry into the feedlot. And lesions associated with an injection should not be a discounting factor when pricing cattle, but rather a sign that the cattle were properly immunized. Many cow-calf and stocker cattle producers are not interested in gathering calves to administer a second clostridial vaccination as indicated by label.

Although the branding vaccination may be the calf's first active exposure to these antigens, calves normally have a high antibody titer to many antigens because of passive transfer of immunoglobulins via colostrum (Tizard, 1992). Cystic lesions are often due to injections given to heifers around breeding or during gestation. George (1995) prove that intramuscular administration of clostridials and certain antibiotics will cause damage so severe that it will be evident in beef muscle 7.5 to 12 mo later. It implies that an injection-site lesion as a proportion of total muscle tissue remains constant and may actually grow with the calf in a manner similar to that which occurs with a hide brand enlarging as the calf grows larger. Morgan et al. (2004) study on many calves inject after 21 days displayed injection sites that were quickly healing but, in some cases, developing fibrous scar and connective tissue surrounding areas of necrosis. The clostridial vaccine and oxytetracycline caused tissue damage that could be identified at 21 days post-injection. Dexter et al. (1994), using a five-point classification system, suggested that chronology of injection-site lesions was related to the healing process and that the injections responsible for the lesions were occurring far in advance of the finishing period. Stocka et al. (1994) reported that the reaction response to tissue injury caused by a vaccine may have a hypersensitivity component, due to repeated exposure to these products.

\section{Method of Injection}

Before injections can be administered, adequate restraint of the animal must be achieved. Every effort should be made to keep the animal as still as possible while the injection is given. This helps prevent broken needles as well as harm to the animal or to the human giving the injection. Shots given to newborn calves in the hindquarters can create soreness in the legs, causing more unnecessary stress on the calf.

\subsection{Syringe}

Needle-free technology first called jet injectors, have been available for humans since the 1930s. (Hingson et al.1963). As the fluid stream forces its way through the tissue, it follows the path of least resistance, resulting in a widely dispersed, spider-web-like distribution of the medication (Grosenbaugh et al., 2004). Needle-free technology improves the dispersion of medication throughout the tissue. Now in the market, there are two different types of non-needle syringe, one is carbon dioxide as the driving force, a piezoelectric actuator is powered, needle-free injectors in North America, Europe and China have been widely used for farm animal epidemic prevention and vaccination.

\section{$<$ Figure 1 $>$}

It is clear that the needle-free injection system will eliminate all residual needles and needle fragments from pork carcasses and it seems likely to reduce injection site lesions resulting from contaminated needles (Hollis et al., 2005). Needle-free technology to vaccinate sheep without damaging the carcass, causing lesions, or leaving needle fragments, and eliciting a similar antibody response as traditional needle vaccinations, has been hampered due to variable wool length (Mousel et al., 2008).

\subsection{Needle/Syringe Care}

Select the needle size to fit the size of the cattle, diameter (gauge) to fit the viscosity of the product, length to fit the route of administration.

$<$ Table 1>

\subsection{Correct Injections}

Correct injections are a common aspect of beef industry but are typically unfamiliar or unknown to beef producers. In general, Subcutaneous Injections are made in the loose skin where the neck and shoulder join. Intramuscular injections given in the thigh muscle or the large muscles along the side of the neck. Intravenous injections (IV) are usually done in the jugular vein. The vein can be distended by manual occlusion of the vessel below (toward the heart) the intended venipuncture site. For both vaccines and antibiotics, the triangular mass of neck muscle is the preferred site for both IM and SC injections. Be sure to inject straight in, not at an angle, when giving IM injections. Use the correct method for SC injections. Do not inject more than $10 \mathrm{cc}$ into one site. When making multiple injections, keep injection sites at least 5 inches apart, being careful not to reuse injection sites. The tail vein is a convenient site for blood collection and IV injections. The tail vein is not visible. It may be accessed by pulling slightly up on the tail, inserting the needle straight upwards on the dorsal midline of the 
tail, between the second and third vertebra of the tail (a shallow groove or depression should be first palpated, this is the venipuncture site).

\section{Conclusions}

The keys to improving the quality and economic value of cattle are management, monitoring and marketing. Proper animal care and correct injection management procedures will significantly improve beef product quality. It was not until the mid-20th century the needle-free syringes were popularized on some farming contexts across the world, with the goals of completing the work on animal vaccines and diagnostic antigens quickly and effectively. Needle-free syringes are not be used for intravenous administration but quite applicable for large-scale vaccination. The producers manage cattle to minimize quality defects by eliminating injection site lesions and drug residues. The research and application of a syringe needle-free vaccine should be strengthened in livestock industry. We can use science and technology to meet expectations for beef quality and safety.

\section{References}

Beef Quality Assurance (BQA). Animal Health Products \& Practices. Available at: http://www.mtbqa.org/06_02.html. Accessed May 5, 2011.

Busby D, Strohbehn D, Dikeman M. (2001). Iowa 4-H Beef Carcass Summary - 1997-2000. 2001 Beef Research Report - Iowa State University. A. S. Leaflet R1761.

Colorado State University study. Available at: http://www.naxcel.com/Naxcel.aspx? country= US\&species $=\mathrm{BF} \& d$ rug $=\mathrm{NX} \& \mathrm{sec}=330$. Accessed May 5, 2011.

Dexter D L, Cowman G L, Morgan J B, Clayton R P, Tatum J D, Sofos J N, Schmidt G R, Glock R D, Smith G C. (1994). Incidence of injection-site blemishes in beef top sirloin butts. J Anim Sci, 72:824-827.

Dubeski P L, Aalhus J L, Van Donkersgoed J, VanderKop M. (2001). Tenderness of beef round muscles containing injection site lesions or bruises. Can. J Anim Sci, 81: 441-450.

George M H, Morgan J B, Glock R D, Tatum J D, Schmidt G R, Sofos J N, Cowman G L, Smith G C. (1995). Injection site lesions: Incidence, tissue histology, collagen concentration, and muscle tenderness in beef rounds. $J$ Anim Sci, 73:3510-3518.

George M H, Cowman G L, Tatum J D, Smith G C. (1996). Incidence and sensory evaluation of injection-site lesions in beef top sirloin butts. J Anim Sci, 74:2095-103.

George M H, Heinrich P E, Dexter D R, Morgan J B, Odde K G, Glock R D, Tatum J D, Cowman G L, Smith G C. (1995). Injection-site lesions in carcasses of cattle receiving injections at branding and at Weaning. J Anim Sci, 73:3235-3240.

Green R D, Field T G, Hammett N S, Ripley B M, Doyle S P. Can cow adaptability and carcass acceptability both be achieved? The Range Beef Cow Symposium XVI December 14, 15 and 16, 1999 - Greeley, Colorado.

Grosenbaugh D A, Leard T, Pardo M C. (2004). Comparison of the safety and efficacy of a recombinant feline leukemia virus (FeLV) vaccine delivered transdermally and an inactivated FeLV vaccine delivered subcutaneously. Vet Ther, 5:258-262.

Hingson R A, Davis H S, Rosen M. (1963). The historical development of jet injection and envisioned uses in mass immunization and mass therapy based upon two decades experience. Mil Med, 128:516-524.

Hollis L C, Smith J F, Johnson B J, Kapil S, Mosier D A. (2005). A Comparison of serological responses when modified-live infectious bovine Rhinotracheitis virus vaccine, Mannheimia haemolytica bacterin-toxoid are administered with needle-free versus conventional needle-based injection in yearling feedlot steers. The Bovine Practitioner, 39:106-109.

Holmgren L N, Reid C. (2001). FFA and 4-H Livestock Project Survey for County and State Sponsored Livestock Shows. Utah State University.

McDowell E, Holtkamp D, Daniels C S. (2010). Heart rate variability and vocalization as a measure of stress response in pigs to needle-free injections versus needle and syringe. AASV Proc 2010. In press.

Mike Baker. (2005). Beef Cattle Comments, Volume 14 Number 6, December.

Mousel M R, Leeds T D, White S N, Hoesing L M. (2008). Technical Note: Comparison of traditional needle vaccination with pneumatic, needle-free vaccination for sheep. $J$ Anim Sci, 86:1468-1471.

Morgan J B, Tittor A W, Lloyd W R. (2004). Influence of ceftiofur sodium biobullet administration on tenderness and tissue damage in beef round muscle. J Anim Sci, 82:3308-3313. 
Rasmussen F. (1980). Tissue damage at the injection site after intramuscular injection of drugs in food-producing animals. In:A.S.J.P.A.M. van Miert, J. Frens, and F. W. van der Kreek (Ed.) Trends in Veterinary Pharmacology and Toxicology: Developments in Animal and Veterinary Sciences 27-33. Elsevier, Amsterdam.

Roeber D L, Cannell R C, Belk K E, Scanga J A, Cowman G L, Smith G C. (2001). Incidence of injection-site lesions in top sirloin butts. J Anim Sci, 79:2615-2618.

Roeber D L, Cannell R C, Wailes W R, Belk K E, Scanga J A, Sofos J N, Cowman G L, Smith G C. (2002). Frequencies of injection-site lesions in muscles from rounds of dairy and beef cow carcasses. $J$ Dairy Sci, 85:532-536.

Svendsen O, Rasmussen F, Neilser P, Steiness E. (1979). The loss of creatinine phosphokinase (CK) from intramuscular injection sites in rabbits. A predictive tool for local toxicology. Acta Pharmacol Toxicol, 44:324-328.

Stier R F. (2003). The dirty dozen: Ways to reduce the 12 biggest foreign materials problems. Food Safety, 9:44-50.

Stocka G L, Edwards A J, Spire M F, Brandt R T, Smith J E. (1994). Inflammatory response to Clostridial vaccines in feedlot cattle. JAVMA, 204:415.

Tizard I R. (1992). Veterinary Immunology: An Introduction (4th Ed.). W. B. Saunders, Philadelphia, PA.

Table 1. Select the needle to fit the cattle size

\begin{tabular}{|c|c|c|c|c|c|c|c|c|c|}
\hline & \multicolumn{9}{|c|}{ Routes of Administration } \\
\hline & \multicolumn{3}{|c|}{$\begin{array}{l}\text { Sub Q Injection } \\
1 / 2 \text { to } 3 / 4 \text { inch needle }\end{array}$} & \multicolumn{3}{|c|}{$\begin{array}{c}\text { Intraveneous injection } \\
1 \frac{1}{2} \text { inch needle }\end{array}$} & \multicolumn{3}{|c|}{$\begin{array}{c}\text { Intramuscular injection } \\
1 \text { to } 1 \frac{1}{2} \text { inch needle }\end{array}$} \\
\hline & \multicolumn{3}{|c|}{ Cattle Weight } & \multicolumn{3}{|c|}{ Cattle Weight } & \multicolumn{3}{|c|}{ Cattle Weight } \\
\hline $\begin{array}{l}\text { Injectable } \\
\text { Viscosity }\end{array}$ & $<300$ & $300-700$ & $>700$ & $<300$ & $300-700$ & $>700$ & $<300$ & $300-700$ & $>700$ \\
\hline $\begin{array}{c}\text { Thin/Watery } \\
\text { Saline, live } \\
\text { virus vaccine }\end{array}$ & $\begin{array}{l}18 \\
\text { gauge }\end{array}$ & $\begin{array}{l}18-16 \\
\text { gauge }\end{array}$ & $\begin{array}{l}16 \\
\text { gauge }\end{array}$ & $\begin{array}{l}18-16 \\
\text { gauge }\end{array}$ & 16 gauge & $\begin{array}{l}16-14 \\
\text { gauge }\end{array}$ & $\begin{array}{l}20-18 \\
\text { gauge }\end{array}$ & $\begin{array}{l}18-16 \\
\text { gauge }\end{array}$ & $\begin{array}{l}18-16 \\
\text { gauge }\end{array}$ \\
\hline $\begin{array}{l}\text { Thick } \\
\text { Biomycin, } \\
\text { L.A.200, } \\
\text { NuFlor }\end{array}$ & $\begin{array}{l}18-16 \\
\text { gauge }\end{array}$ & $\begin{array}{l}18-16 \\
\text { gauge }\end{array}$ & $\begin{array}{l}16 \\
\text { gauge }\end{array}$ & $\begin{array}{l}16 \\
\text { gauge }\end{array}$ & $\begin{array}{l}16-14 \\
\text { gauge }\end{array}$ & $\begin{array}{l}16-14 \\
\text { gauge }\end{array}$ & $\begin{array}{l}18 \\
\text { gauge }\end{array}$ & 16 gauge & $\begin{array}{l}16 \\
\text { gauge }\end{array}$ \\
\hline & the & lle to $\mathrm{fi}$ & cattl & e (the & allest pr & cal siz & hout $\mathrm{b}$ & ding) & \\
\hline
\end{tabular}

Note: Mike Baker, Beef Cattle Comments, Volume 14 Number 6, December, 2005. 


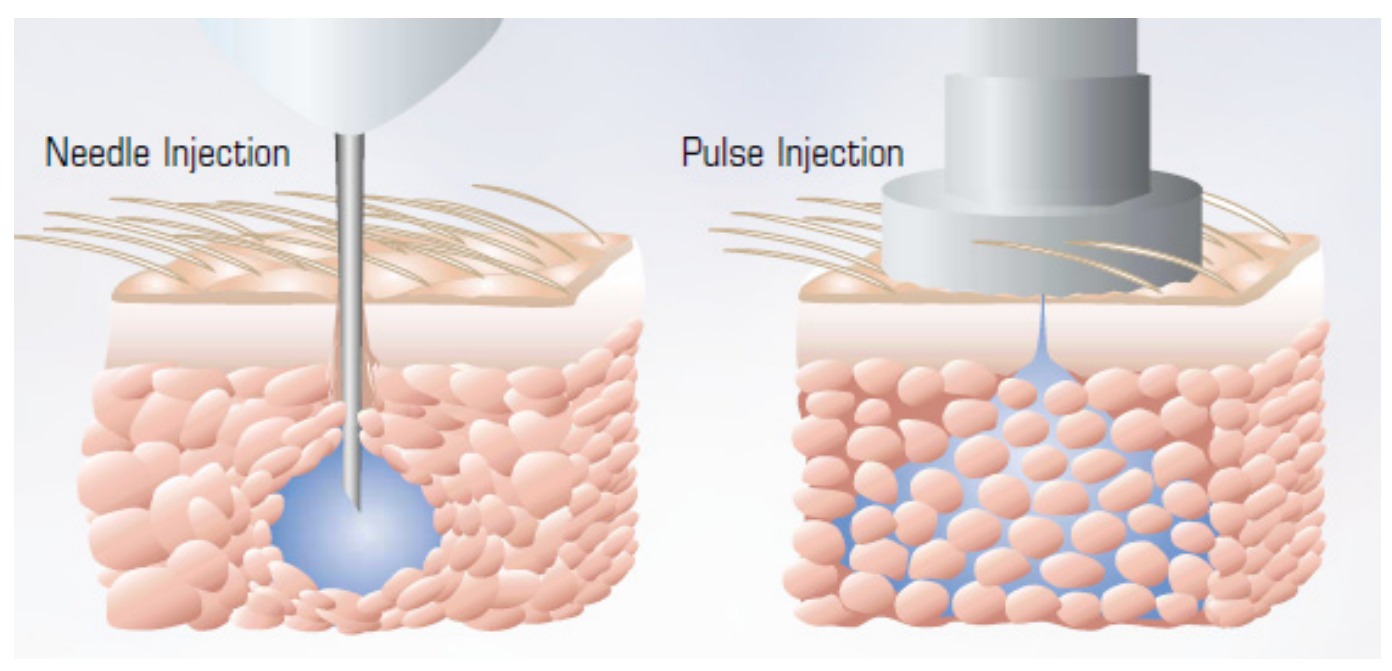

Figure 1. Trans-dermal injections 